\title{
Studies on type $\mathrm{G}$ influenza virus in the chick embryo
}

\author{
By ROY JENNINGS AND M. J. FREEMAN \\ Division of Virology, School of Medicine, \\ The University of Leeds, Leeds 2
}

(Received 17 June 1971)

\begin{abstract}
SUMMARY
The effect of varying conditions of inoculation and incubation on the growth of type $\mathrm{C}$ influenza virus in the allantoic cavity of the developing chick embryo were investigated. It was found that the highest yields of both virus haemagglutinin and infectious virus were obtained following the inoculation of chick embryos at 8 days with subsequent incubation at $32^{\circ} \mathrm{C}$. Using the chick embryo allantoic cavity for titration of infectious virus, growth curves of allantoically propagated virus under varying inoculation and incubation conditions were determined.
\end{abstract}

\section{INTRODUCTION}

Although type $\mathrm{C}$ influenza virus is recovered only infrequently from infections in man, it appears to be widespread in nature and, since the initial isolation of the virus in 1947 from an individual with a mild respiratory tract infection (Taylor, 1949), strains of influenza type $C$ have been recovered in many areas of the world (Fukumi, Sunakana, Takaki \& Tanaka, 1951; Zhdanov, 1959; Veeraraghavan, 1961 ; Jennings \& Grant, 1967). Antibodies to type C influenza virus are common in sera from most age groups of the population as surveys carried out in England (Andrews \& MacDonald, 1955), North America (Davenport, Hennessy \& Francis, 1953) and the Caribbean (Jennings, 1968) have shown.

The infrequent isolation of the virus may be due, at least in part, to the type of infection produced which is usually a sporadic, mild or asymptomatic upper respiratory tract illness, while the high incidence of type $\mathrm{C}$ influenza virus antibody may result from a high rate of re-infection (Zhdanov, 1959).

Detailed studies on the biological properties and laboratory behaviour of type $\mathrm{C}$ influenza virus may be hampered by the difficulties often encountered in propagating the virus in any system other than the amniotic cavity of the chick embryo. Several attempts have been made to cultivate the virus in laboratory animals (Taylor, 1951; Morozenko, 1957) and in tissue cultures (Green, Lieberman \& Mogabgab, 1957; Korych \& Frankova, 1966) but with little success. Following the intra-allantoic inoculation of chick embryos, the production of infectious virus and virus haemagglutinin by type $\mathrm{C}$ influenza virus has been reported as erratic and irregular (Taylor, 1951), the titres obtained often being considerably lower than those produced in the amniotic cavity.

However, more recent reports have suggested that satisfactory growth of the 
virus does occur in the allantois if incubation is carried out at $32^{\circ}$ to $33^{\circ} \mathrm{C}$. for 72-84 hr. (Deichman, 1958; Styk, 1963), and use of this system may facilitate studies on some biological properties of the virus.

The present report confirms that type $\mathrm{C}$ influenza can be cultivated in the chick embryo allantoic cavity and determines the conditions of inoculation and incubation leading to the greatest yields of virus.

\section{Virus}

\section{MATERIALS AND METHODS}

The 1233 strain of influenza type $C$ virus (C/1233), originally isolated in 1947 (Taylor, 1949), was obtained from the Research Reference Reagents Branch of the National Institute of Allergy and Infectious Diseases, Bethesda, Maryland, U.S.A. The virus received 13 serial passages in the amniotic cavity of 10- or 11-day-old chick embryos in our laboratory after which an amniotic fluid pool of the virus was prepared and used for studies on virus growth in the chick embryo allantoic sac. The identity of the virus was confirmed by haemagglutination-inhibition tests against influenza A, B, C and parainfluenza standard reference antisera.

\section{Infectivity titrations}

Infectious virus was assayed in either the amniotic (AEID 50) or allantoic (EID 50) cavities of the chick embryo. For titration in the amniotic cavity, serial tenfold dilutions of the virus samples to be assayed were prepared in chilled Dulbecco 'A' phosphate-buffered saline (PBS), $\mathrm{pH} 7 \cdot 3$, and each dilution inoculated into three 10- or 11-day-old chick embryos. The volume of inoculum used was $0.1 \mathrm{ml}$. per embryo and incubation was at $35^{\circ} \mathrm{C}$. for $48 \mathrm{hr}$.

For infectivity titrations by the allantoic route, virus dilutions were prepared as described above but embryos were inoculated at 8 days and incubated subsequently at $32^{\circ} \mathrm{C}$. for $72 \mathrm{hr}$. Three eggs were used per dilution and the inoculum volume was $0.2 \mathrm{ml}$. per egg.

After incubation for the appropriate length of time the embryos were chilled at $4^{\circ} \mathrm{C}$., either amniotic or allantoic fluids collected and each fluid spot-tested individually for the presence of virus haemagglutinin using a $1 \%$ suspension of chicken erythrocytes in $0.85 \%$ saline. The $50 \%$ end-points were calculated according to the method of Reed \& Muench (1938).

\section{Haemagglutination titrations}

Virus haemagglutinin was assayed in Perspex trays by standard methods (WHO Expert Committee on Influenza, 1953), using an $0.5 \%$ suspension of chicken erythrocytes prepared in $0.85 \%$ saline. Virus dilutions were made in saline and all haemagglutination (HA) tests with influenza $\mathrm{C} / 1233$ were performed at $4^{\circ} \mathrm{C}$. 
RESULTS

Production of haemagglutinin by $C / 1233$ in the chick embryo allantois

To determine optimum conditions for the growth and production of haemagglutinin by influenza type $\mathrm{C} / 1233$ in the chick embryo allantoic cavity, a pool of amniotically propagated virus containing 6400 haemagglutinating units per $\mathrm{ml}$. (HAU/ml.) and 1010.0 AEID50 per ml. was inoculated intra-allantoically, in $0.2 \mathrm{ml}$. amounts, into groups of embryos aged either 8 or 10 days and these were incubated subsequently at either $32^{\circ}$ or $35^{\circ} \mathrm{C}$. The inoculum dilutions, prepared in cold PBS, contained $10^{3.0}, 10^{4 \cdot 0}$ and $10^{5 \cdot 0}$ AEID 50/0.1 ml. After incubation for $72 \mathrm{hr}$., the embryos were chilled, the allantoic fluids collected and tested individually for virus haemagglutinin.

Table 1 shows the combined results of this experiment as the concentration of virus in the inoculum had no apparent effect on the incidence or level of virus haemagglutinin. Studies in this laboratory (Prasad, 1971) have failed to demonstrate the von Magnus phenomenon with influenza $C$ virus. A significantly greater percentage of allantoic fluids collected from embryos inoculated at 8 days, in contrast to fluids from embryos inoculated at 10 days, contained detectable virus haemagglutinin, irrespective of the temperature of incubation. However, there appeared to be some effect of incubation temperature on the production of virus haemagglutinin, and in fluids collected from embryos inoculated at 10 days virus haemagglutinin was detected most frequently after incubation at $32^{\circ}$ as opposed to $35^{\circ} \mathrm{C}$. Similarly, in allantoic fluids from embryos inoculated at 8 days, the presence of haemagglutinin was observed slightly more frequently after incubation at the lower temperature.

Table 1 also shows the percentage of the positive allantoic fluids with virus haemagglutinin titres of at least $400 \mathrm{HAU} / \mathrm{ml}$. Such relatively high titres were commonly observed only in allantoic fluids collected from embryos inoculated at 8 days and incubated subsequently at $32^{\circ} \mathrm{C}$., and $22(45 \%)$ of these fluids were observed to have titres of at least $400 \mathrm{HAU} / \mathrm{ml}$. The least successful conditions for the production of influenza $\mathrm{C} / 1233$ haemagglutinin followed the inoculation of embryos at 10 days and incubation of these embryos at $35^{\circ} \mathrm{C}$.

Table 1. Production of virus haemagglutinin by amniotically propagated influenza $C$ in the chick embryo allantois

\begin{tabular}{|c|c|c|c|c|c|}
\hline \multirow{2}{*}{$\begin{array}{c}\text { Embryo age } \\
\text { at inoculation } \\
\text { (days) }\end{array}$} & \multirow{2}{*}{$\begin{array}{c}\text { Incubation } \\
\text { temperature } \\
\left({ }^{\circ} \mathrm{C}\right)\end{array}$} & \multirow{2}{*}{$\begin{array}{l}\text { Number of } \\
\text { fluids tested }\end{array}$} & \multicolumn{2}{|c|}{$\begin{array}{l}\text { Fluids positive for } \\
\text { haemagglutinin }\end{array}$} & \multirow{2}{*}{$\begin{array}{l}\text { Positive fluids } \\
\text { with titres } \\
\text { > } 400 \mathrm{HAU} / \mathrm{ml} . \\
(\%)\end{array}$} \\
\hline & & & No. & $\%$ & \\
\hline 8 & 32 & 63 & 49 & $77 \cdot 9$ & $44 \cdot 9$ \\
\hline 8 & 35 & 63 & 45 & $71 \cdot 4$ & $13 \cdot 7$ \\
\hline 10 & 32 & 49 & 32 & $65 \cdot 4$ & $19 \cdot 1$ \\
\hline 10 & 35 & 54 & 17 & $31 \cdot 7$ & $17 \cdot 6$ \\
\hline Totals & & 229 & 143 & $62 \cdot 3$ & $25 \cdot 8$ \\
\hline
\end{tabular}




\section{Production of infectious virus by $C / 1233$ in the chick embryo allantois}

The production of infectious virus following the intra-allantoic inoculation of amniotically propagated influenza type $\mathrm{C} / 1233$ into chick embryos was examined in four separate experiments. In each of these groups embryos aged 8 or 10 days were inoculated intro-allantoically with $0.2 \mathrm{ml}$. amounts of an amniotic fluid pool

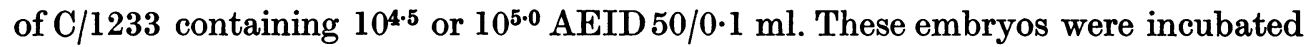
at either $32^{\circ}$ or $35^{\circ} \mathrm{C}$. for $72 \mathrm{hr}$. After chilling, the infected allantoic fluids were collected and equal volumes pooled according to embryo age at inoculation and temperature of incubation. These pools were then titrated, intra-amniotically, for infectious virus and also tested for virus haemagglutinin.

The results of these experiments are shown in Table 2 and it can be seen that, for each experiment, the amount of infectious virus varied little under the different conditions, with the exception that the titres of infectious virus in allantoic fluid pools prepared from embryos inoculated at 8 days and incubated subsequently at $32^{\circ} \mathrm{C}$. were always at least tenfold higher than the values observed in pools from embryos inoculated at 10 days or incubated at $35^{\circ} \mathrm{C}$.

\section{Serial passage of influenza $C / 1233$ in the chick embryo allantois}

Amniotically propagated influenza type $\mathrm{C} / 1233$ was now subjected to a series of passages in the chick embryo allantoic cavity, under those conditions which appeared from the above experiments to result in the best yields of infectious virus and virus haemagglutinin. Virus dilutions in chilled PBS were inoculated, in $0.2 \mathrm{ml}$. amounts, intra-allantoically into groups of 8-day-old embryos at each passage and these were incubated at $32^{\circ} \mathrm{C}$. for $72 \mathrm{hr}$. The titres of virus haemagglutinin were determined in each allantoic fluid at each passage. At the tenth passage level an allantoic fluid pool of the virus was prepared and assayed for infectious virus, using the intra-allantoic method, and for virus haemagglutinin. This pool contained $1280 \mathrm{HAU} / \mathrm{ml}$. and an infectivity titre of $10^{9 \cdot 2} \mathrm{EID} \mathrm{50} / \mathrm{ml}$.

\section{Growth of allantoically propagated $C / 1233$ in the chick embryo allantois}

Two experiments to determine the growth curves produced by allantoically propagated influenza $\mathrm{C}$ in the chick embryo allantoic cavity under varying conditions of inoculation and incubation were now carried out. In one, growth of C/1233 in chick embryos inoculated at 8 days and incubated subsequently at either $29^{\circ}$, $32^{\circ}$ or $35^{\circ} \mathrm{C}$. was compared. In the second experiment, production of virus haemagglutinin and infectious virus after the inoculation of C/1233 into 6-, 8- or 10-day-old embryos incubated subsequently at $32^{\circ} \mathrm{C}$. were compared.

Both experiments were performed in the same way. Chick embryos aged 6, 8 or 10 days were each inoculated with $0.2 \mathrm{ml}$. of allantoically propagated $\mathrm{C} / 1233$ diluted in chilled PBS to contain $10^{3.5}$ EID 50/0.2 ml., and incubated at the appropriate temperature. At intervals after inoculation, groups of four embryos were chilled, the allantoic fluids collected and equal volumes pooled. These pools were stored at $-70^{\circ} \mathrm{C}$. before assay for haemagglutinin and infectious virus. Infectivity titrations were carried out by the intra-allantoic method. 


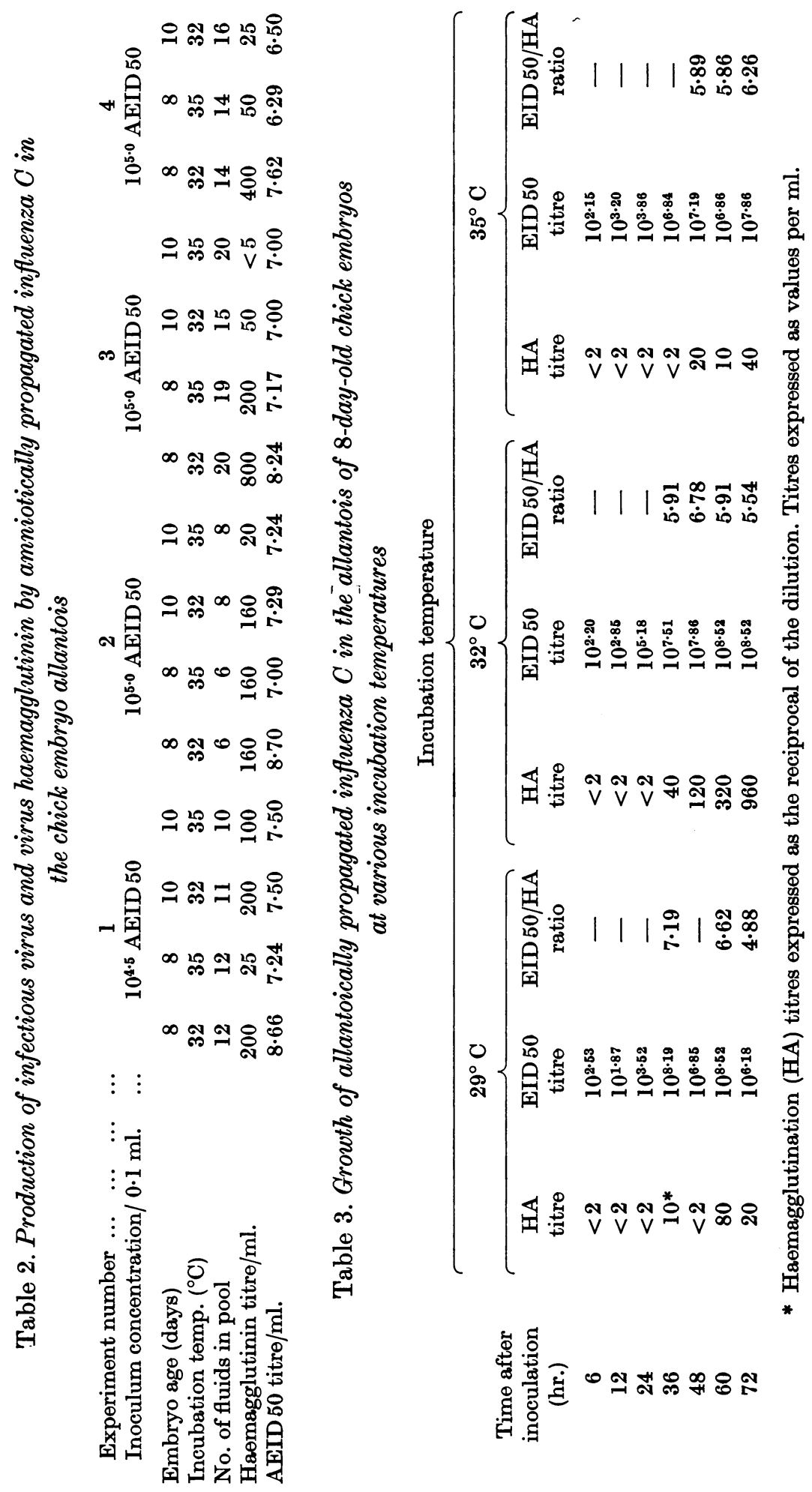




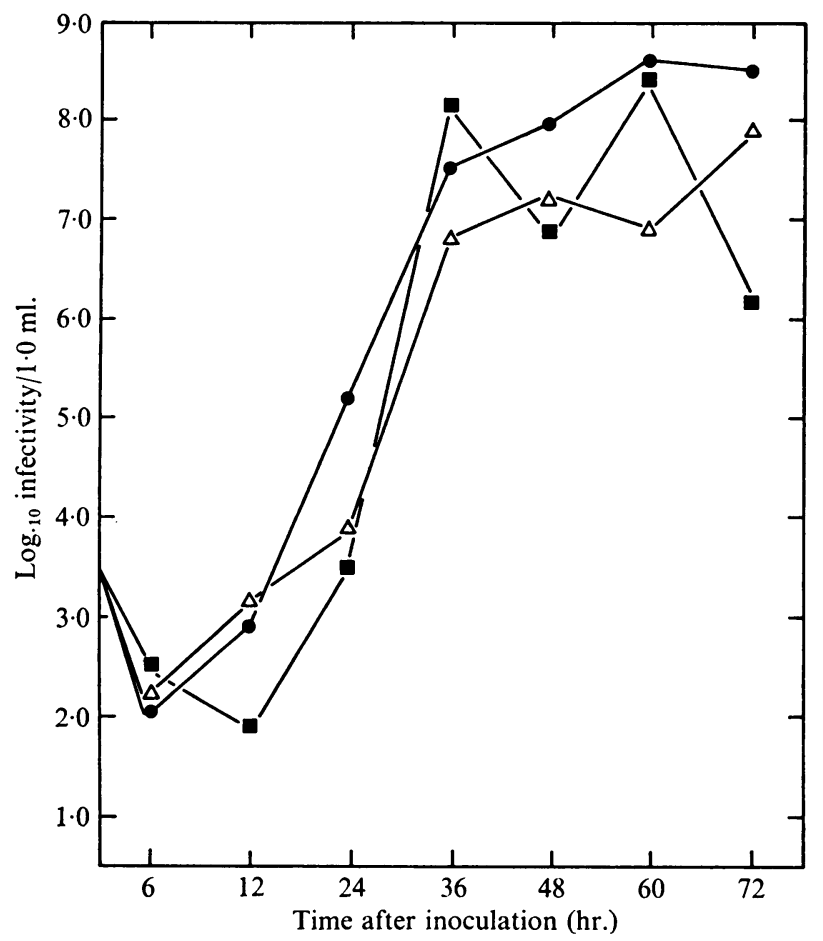

Fig. 1. Growth curves of influenza $\mathrm{C} / \mathbf{1 2 3 3}$ in the allantois of 8-day-old eggs after incubation at various temperatures.

$\square, 29^{\circ} ; \bullet-0,32^{\circ} ; \triangle-\triangle, 35^{\circ}$.

Fig. 1 shows the growth curves obtained following incubation at various temperatures after inoculation of virus into embryos at 8 days. Relatively high titres of infectious virus were observed at $32^{\circ} \mathrm{C}$. and growth was rapid in the early stages of infection at this temperature. The amount of infectious virus present after $72 \mathrm{hr}$. at $32^{\circ} \mathrm{C}$. was greater than that observed after incubation at $29^{\circ}$ or $35^{\circ} \mathrm{C}$. for the same period. The infectious virus titres at the higher temperature never reached those observed at $32^{\circ} \mathrm{C}$., while at $29^{\circ} \mathrm{C}$. the production of infectious virus appeared more variable.

The titres of infectious virus, together with the haemagglutinin and EID 50/HA ratios, are shown in Table 3 . At 48, 60 and $72 \mathrm{hr}$. after infection, the virus haemagglutinin titres in the pooled allantoic fluids from embryos incubated at $32^{\circ} \mathrm{C}$. were at least fourfold greater than in pools from those incubated at $29^{\circ}$ or $35^{\circ} \mathrm{C}$. At all temperatures haemagglutinin was undetectable before $36 \mathrm{hr}$. after virus inoculation.

In Fig. 2 the growth curves obtained after the intra-allantoic inoculation of chick embryos at 6,8 or 10 days with subsequent incubation at $32^{\circ} \mathrm{C}$. are shown. The greatest amount of infectious virus was observed in allantoic fluid pools collected at $60 \mathrm{hr}$. from embryos inoculated at 8 days. The infectivity titres in pools from 6- and 10-day-old embryos approached this value at $60 \mathrm{hr}$., but in embryos inoculated at 10 days, the titre had dropped considerably by $84 \mathrm{hr}$. The production of virus haemagglutinin at 72 and $84 \mathrm{hr}$. was highest in embryos 


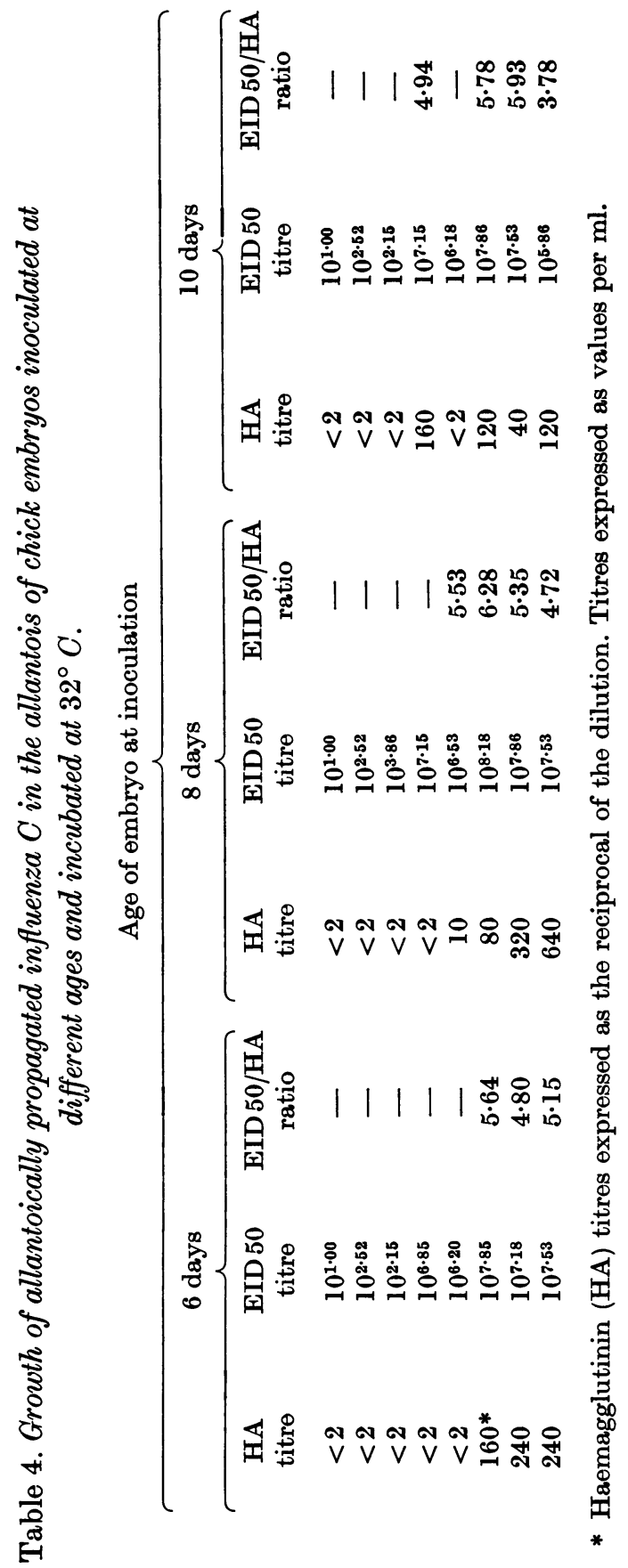

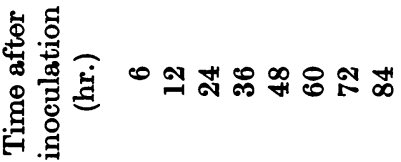




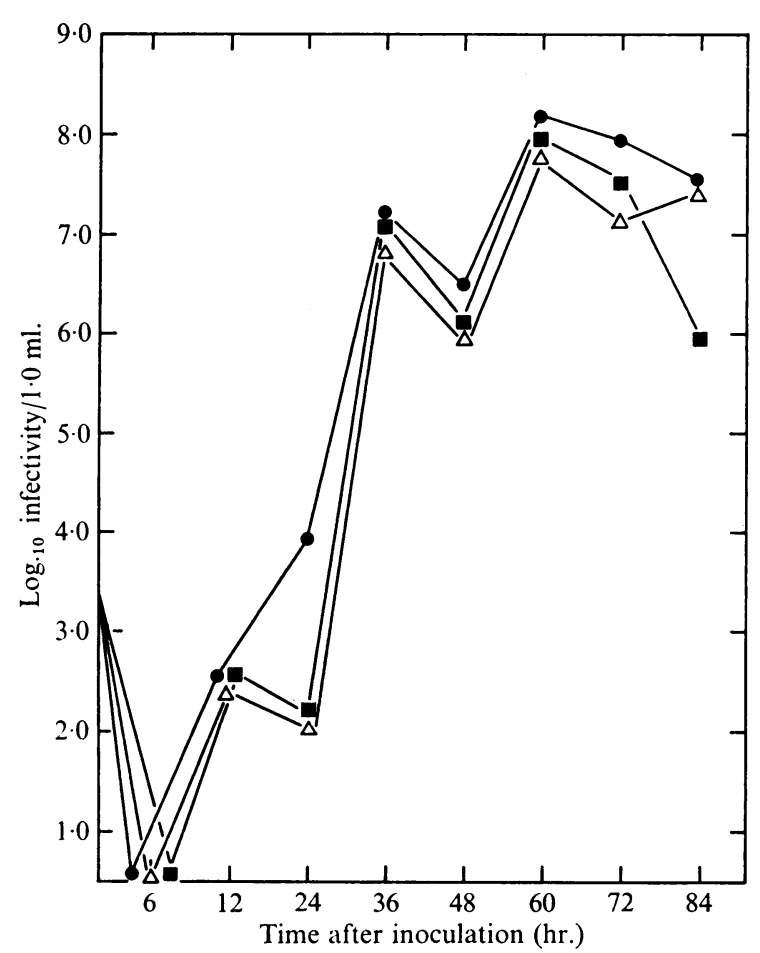

Fig. 2. Growth curves of influenza $\mathrm{C} / 1233$ in the allantois of 6-, 8- and 10-day-old eggs incubated at $32^{\circ} . \triangle-\triangle$, 6-day-old eggs; $-\bullet, 8$-day-old eggs; $\square-\square, 10$-day-old eggs.

inoculated at 8 days (Table 4), but was undetectable before $48 \mathrm{hr}$. after infection. In allantoic fluid pools from embryos infected at 6 days, virus haemagglutinin remained undetectable before $60 \mathrm{hr}$. after infection.

\section{DISCUSSION}

Although antibody studies suggest that type $\mathrm{C}$ influenza virus is a common pathogen of man (Davenport et al. 1953; Andrews \& MacDonald, 1955; Jennings, 1968 ) it is usually associated with mild or inapparent infections (Zhdanov, 1959). It is perhaps for this reason, combined with the lack of a suitable system for cultivation which, besides consistently producing adequate quantities of virus, lends itself readily to experimentation, that type $\mathrm{C}$ influenza virus is rarely subjected to laboratory examination. The present work was carried out to explore the possibilities of using the chick embryo allantoic cavity for investigating some biological properties of the virus.

Taylor (1951) endeavoured to grow influenza type $C$ in the allantois of the developing chick embryo. He reported that, in eight attempts to cultivate amniotically propagated virus after intra-allantoic inoculation, virus haemagglutinin was observed only once. Taylor also found that growth of influenza type $\mathrm{C}$ was inconsistent and unpredictable on serial passage in the allantoic cavity. However, 
satisfactory multiplication of $\mathrm{C} / 1233$ in the allantoic sac of 10-day-old embryos incubated at $32^{\circ}$ to $33^{\circ} \mathrm{C}$. has been reported more recently by Styk (1963), and Cantell et al. (1965) observed influenza type C haemagglutinin titres of 32-256 $\mathrm{HAU} / \mathrm{ml}$. in fluids from embryos inoculated intro-allantoically at 8 days and incubated at $37^{\circ} \mathrm{C}$.

The present study confirms the ability of amniotically propagated influenza $\mathrm{C}$ to grow satisfactorily in the chick embryo allantois, and shows that the greatest quantities of haemagglutinin and infectious virus are obtained by infecting embryos at 8 days with subsequent incubation at $32^{\circ} \mathrm{C}$. Under these conditions the titres of infectious virus frequently reached $10^{8.0} \mathrm{AEID} 50 / \mathrm{ml}$., while haemagglutinin titres above $400 \mathrm{HAU} / \mathrm{ml}$. were commonly observed in individual allantoic fluids.

However, growth of amniotically propagated influenza $\mathrm{C}$ in the allantois compares unfavourably with growth in the amnion in two ways. First, the production of haemagglutinin by $\mathrm{C} / \mathbf{1 2 3 3}$ in the allantois appears to be affected considerably by egg to egg variation. Thus, only $62 \%$ of all the allantoic fluids examined, irrespective of embryo age at inoculation and incubation temperature, contained detectable virus haemagglutinin. This variation is much less after the intraamniotic inoculation of influenza $\mathrm{C}$, but it does agree with the findings of Taylor (1951). Egg to egg variation is significantly reduced, however, in embryos inoculated intra-allantoically at 8 days and incubated at $32^{\circ} \mathrm{C}$. when virus haemagglutinin is found in almost $80 \%$ of the infected allantoic fluids. Secondly, the infectivity titres observed in allantoic fluid pools prepared after the intra-allantoic inoculation of amniotically propagated influenza $\mathrm{C}$ are usually 10 - to 100 -fold lower than the titres observed in the amnion, while the titres of virus haemagglutinin in the allantois are often tenfold lower than those found in the amnion.

Nevertheless, the allantoic inoculation of chick embryos at 8 days followed by incubation at $32^{\circ} \mathrm{C}$. does provide satisfactory yields of infectious virus and virus haemagglutinin in pooled allantoic fluids and may enable some biological properties of influenza type $\mathrm{C}$ to be examined more readily. The EID 50/HA ratios for $\mathrm{C} / 1233$ in the allantois compare well with values obtained after inoculation into the amnion (Isaacs \& Donald, 1955).

Ten serial passages of influenza type $\mathrm{C}$ in the allantois of 8-day-old embryos at $32^{\circ} \mathrm{C}$. failed to increase the titre of infectious virus significantly, while the production of haemagglutinin remained somewhat variable. In pooled allantoic fluids haemagglutinin titres ranging from 400 to $1600 \mathrm{HAU} / \mathrm{ml}$. could normally be obtained. Allantoically propagated influenza type $\mathrm{C}$ produced less haemagglutinin and infectious virus when incubated at temperatures above or below $32^{\circ} \mathrm{C}$. in embryos older or younger than 8 days. These results are in contrast to findings with the PR8 strain of influenza type A (Miller, 1944) which was best cultivated in the allantoic cavity at $36^{\circ} \mathrm{C}$. and produced lower haemagglutinin titres at $33^{\circ} \mathrm{C}$. Early studies on the Lee strain of influenza type B showed that the greatest amounts of haemagglutinin and infectious virus were produced at $35^{\circ} \mathrm{C}$. (McLean et al. 1944). It is interesting to note that the age of the chick embryo at inoculation affects the growth of some parainfluenza viruses in the allantoic cavity (Hsuing \& 
Van de Water, 1966), but this factor appears to play little part in the replication of influenza types $A$ and $B$ viruses.

Another group of respiratory viruses, the rhinoviruses, when cultivated in some tissue culture systems, resemble influenza type $\mathrm{C}$ in growing best at $32^{\circ}$ to $33^{\circ} \mathrm{C}$. (Tyrrell \& Parsons, 1960). These viruses, like influenza C, are primarily pathogens of the upper respiratory tract in man and are associated with mild infections.

The authors wish to express their gratitude to Dr J. W. Czekalowski and Dr D. Hobson for their advice and encouragement during the preparation of this paper.

\section{REFERENCES}

Andrews, B. E. \& McDonald, J. C. (1955). Influenza virus C infection in England. British Medical Journal ii, 992.

Cantell, K., Valle, M., Schakir, R., Saukkonen, J. J. \& Uroma, E. (1965). Observations on production, assay and purification of chick embryo interferon. Annales medicinae experimentalis et biologiae Fenniae 43, 125.

Davenport, F. M., Hennessy, A. V. \& Francis, T. Jr. (1953). Epidemiologic and immunologic significance of age distribution of antibody to antigenic variants of influenza virus. Journal of Experimental Medicine 98, 641.

Deichman, G. I. (1958). Features of the multiplication of type C (1233 strain) influenza virus in the allantoic cavity of chick embryos. Problems of Virology 3, 189.

Fukumi, H., Sunakana, S., Takaki, A. \& Tanaka, K. (1951). Influenza C in Japan. Japanese Medical Journal 4, 139.

Green, I. J., Lieberman, M. \& Mogabgab, W. J. (1957). The behaviour of influenza viruses in various tissue culture systems. Journal of Immunology 78, 233.

Hsuing, G. D. \& VAn De Water, T. (1966). Production of interferon in embryonated eggs and in cell cultures infected with Simian virus 5. Proceedings of the Society for Experimental Biology and Medicine 123, 840.

IsaACS, A. \& Donald, H. B. (1955). Particle counts of haemagglutinating viruses. Journal of General Microbiology 12, 241.

Jennings, R. (1968). Respiratory viruses in Jamaica: A virologic and serologic study. 3. Haemagglutination-inhibiting antibodies to type $\mathrm{B}$ and $\mathrm{C}$ influenza viruses in the sera of Jamaicans. Americal Journal of Epidemiology 87, 440.

Jennings, R. \& Grant, L. S. (1967). Respiratory viruses in Jamaica: A virologic and serologic study. 1. Virus isolations and serologic studies on clinical specimens. American Journal of Epidemiology 86, 690.

Korych, B. \& Frankova, V. (1966). Possibility of employing porcine kidney tissue cultures for quantitative determinations of Myxovirus influenzae C. Ceskoslovenská epidemiologie, mikrobiologie, imunologie 15, 135.

Mclean, I. W., Beard, D., Taylor, A. R., Sharp, D. G., Beard, J. W., Feller, A. E. \& DiNGLE, S. H. (1944). Influence of temperature of incubation on increase of influenzal virus B (Lee strain) in chorioallantoic fluid of chick embryos. Journal of Immunology 48, 305.

Miller, G. L. (1944). A study of conditions for the optimum production of PR 8 influenza virus in chick embryos. Journal of Experimental Medicine 79, 173.

Morozenko, M. A. (1957). Biological properties of type C influenza virus. Problems of Virology 2, 369.

Prasad, A. K. (1971). Studies on influenza virus type C. Ph.D. Thesis, University of Leeds.

REed, L. J. \& MUENCH, H. (1938). A simple method of estimating 50 per cent endpoints. American Journal of Hygiene 27, 493.

STYK, B. (1963). Effect of some inhibitor-destroying substances on the non-specific inhibitor of $\mathrm{C}$ influenza virus present in normal rat serum. Acta Virologica 7, 88.

TAYLOR, R. M. (1949). Studies on survival of influenza virus between epidemics and antigenic variants of the virus. American Journal of Public Health 39, 171.

TAYlor, R. M. (1951). A further note on 1233 ('influenza C') virus. Archiv für die gesamte Virusforschung 14, 189. 
Tyrrell, D. A. J. \& Parsons, R. (1960). Some virus isolations from common colds. 3. Cytopathic effects in tissue cultures. Lancet i, 239.

Veeraraghavan, N. (1961). Influenza virus isolations at the Government of India Influenza Centre, Coonoor, during 1959-60. Bulletin of the World Health Organization 24, 679.

World Health Organization Expert Committee on Influenza (1953). Technical Report Series of the World Health Organization, No. 64.

Zhdanov, V. M. (1959). Results of further research on influenza in the U.S.S.R. with special reference to the 1957 pandemic. Bulletin of the World Health Organization 20, 261. 